\title{
Salmonella Isolated from Animals and Feedstuffs in Sweden during 1988-1992
}

\author{
By M. Malmqvist ${ }^{1}$, K.-G. Jacobsson ${ }^{1}$, P. Häggblom ${ }^{1}$, F. Cerenius $^{2}$, L. Sjöland ${ }^{2}$, and A. Gun- \\ narsson $^{1}$
}

${ }^{1}$ The National Veterinary Institute, Uppsala, and ${ }^{2}$ The Swedish Board of Agriculture, Jönköping, Sweden.

\begin{abstract}
Malmqvist, M., K.-G. Jacobsson, P. Häggblom, F. Cerenius, L. Sjöland and A. Gunnarsson: Salmonella isolated from animals and feedstuffs in Sweden during 1988-1992. Acta vet. scand. 1995, 36, 21-39. - The present paper surveys the number of Salmonella isolations in animals and feedstuffs in Sweden during 1988-1992. It is the eighth in a series of reports published by the National Veterinary Institute (NVI) since 1949. During the period referred to, 602 outbreaks of Salmonella were reported in animals, both domestic and wild. Compared with the previous 5-year period there was a $20 \%$ reduction in the number of outbreaks (760). Fifty-six different serotypes were reported, 19 of which had never been isolated in any animal in Sweden previously. A temporary increase in the number of outbreaks in poultry was seen in 1991 following an extended sampling before slaughter of layers. A remarkably high prevalence (38\%) of Salmonella was observed in snakes in the wild.

In 1990, the end-point testing of feeds was replaced by an approach based on HACCP (Hazard Analysis Critical Control Point) principles for the monitoring of feed mills. Significantly higher number of Salmonella positive samples were found by using this technique compared with the previous analysis of finished feed.

It is concluded that the adopted Salmonella control program has contributed to a reduced number of Salmonella outbreaks in animals in Sweden.
\end{abstract}

Salmonella isolations.

\section{Introduction}

Salmonellosis is one of the most important foodborne diseases. During the last 35 years, Sweden has developed national control programs in order to prevent Salmonella from contaminating food. Foodborne infections caused by Salmonella in Sweden are rare and the presence of Salmonella in domestic animals is extremely low.

The present survey, covering 1988-1992, is the 8 th in a series of papers on the number of $\mathrm{Sal}$ monella isolated from animals and feedstuffs in Sweden since 1949. These reports, published by the National Veterinary Institute
(NVI Thal et al. 1957, Rutqvist \& Thal 1958, Karlsson et al. 1963, Hurvell et al. 1969, Gunnarsson et al. 1974, Sandstedt et al. 1980, Mårtensson et al. 1984, Eld et al. 1991), have become valuable instruments in the evaluation and control of Salmonella in this country. By provisions issued by the Swedish Board of Agriculture (SBA), all isolations of Salmonella must be identified and reported to SBA as well as to the State Epizootiologist. Official monthly summaries based on each report are published by the SBA. The present survey is based partly on these summaries and partly 
Table 1. Outbreaks of Salmonella enterica in animals in Sweden 1968-1992. Distribution in different subspecies.

\begin{tabular}{|c|c|c|c|c|c|}
\hline & $1968-1972$ & 1973-1977 & $1978-1982$ & $1983-1987$ & 1988-1992 \\
\hline \multicolumn{6}{|l|}{$\begin{array}{l}\text { Subspecies enterica } \\
\text { formerly named }\end{array}$} \\
\hline Subspecies I & 1721 & 1077 & 1231 & 720 & 524 \\
\hline \multicolumn{6}{|l|}{$\begin{array}{l}\text { Subspecies salamae } \\
\text { formerly named }\end{array}$} \\
\hline Subspecies II & 10 & 2 & 4 & 6 & 11 \\
\hline \multicolumn{6}{|l|}{$\begin{array}{l}\text { Subspecies arizonae } \\
\text { and diarizonae } \\
\text { formerly named }\end{array}$} \\
\hline Subspecies IIIa \& IIIb & 14 & 19 & 14 & 13 & 59 \\
\hline \multicolumn{6}{|l|}{$\begin{array}{l}\text { Subspecies houtenae } \\
\text { formerly named }\end{array}$} \\
\hline Subspecies IV & 1 & 2 & 1 & 3 & 4 \\
\hline $\begin{array}{l}\text { Salmonella not } \\
\text { typed or typable }\end{array}$ & 6 & 16 & 18 & 4 & \\
\hline Total & 1746 & 1106 & 1266 & 760 & 602 \\
\hline
\end{tabular}

on the compilation of laboratory journals at the NVI.

\section{Materials and methods}

When strains of Salmonella have been isolated at regional veterinary laboratories or at the NVI, they have to be confirmed and identified at the NVI. This procedure has been performed according to Kauffman (1972). Phage typing of $S$. Typhimurium has been made by the National Bacteriological Laboratory (NBL) Stockholm, using a method developed by Lilleengen (1948). The term outbreak is used regardless of the origin of the isolation, whether from clinical cases or necropsies of domestic or wild animals. If an identical strain is isolated in several animals of the same species in the same herd within 1 year, only 1 outbreak is recorded. If more than 1 serotype is isolated in the same herd each new isolation is recorded as a new outbreak. Each isolation in wild animals is considered to be 1 outbreak.
The nomenclature used refers to the Taxonomy of the genus Salmonella given by WHO Collaborating Centre for Reference and Research on Salmonella (1992), Institut Pasteur, Paris.

\section{Results and discussion \\ Salmonella in animals}

The total number of Salmonella outbreaks in animals during the period $1988-92$ was 602 , all of which were of the species $S$. enterica. The distribution in different subspecies is listed in Table 1 . Subspecies enterica (formerly named subspecies I) comprised $87 \%$ of the cases (524), subspecies salamae (formerly named subspecies II) $2 \%$ (11), subspecies arizonae and diarizonae (formerly named subspecies IIIa and IIIb) $10 \%$ (59), and subspecies houtenae (formerly named subspecies IV) $1 \%$ (4). The outbreaks from 4 previous 5year-periods are listed in the same table. A comparison with earlier figures of the total 


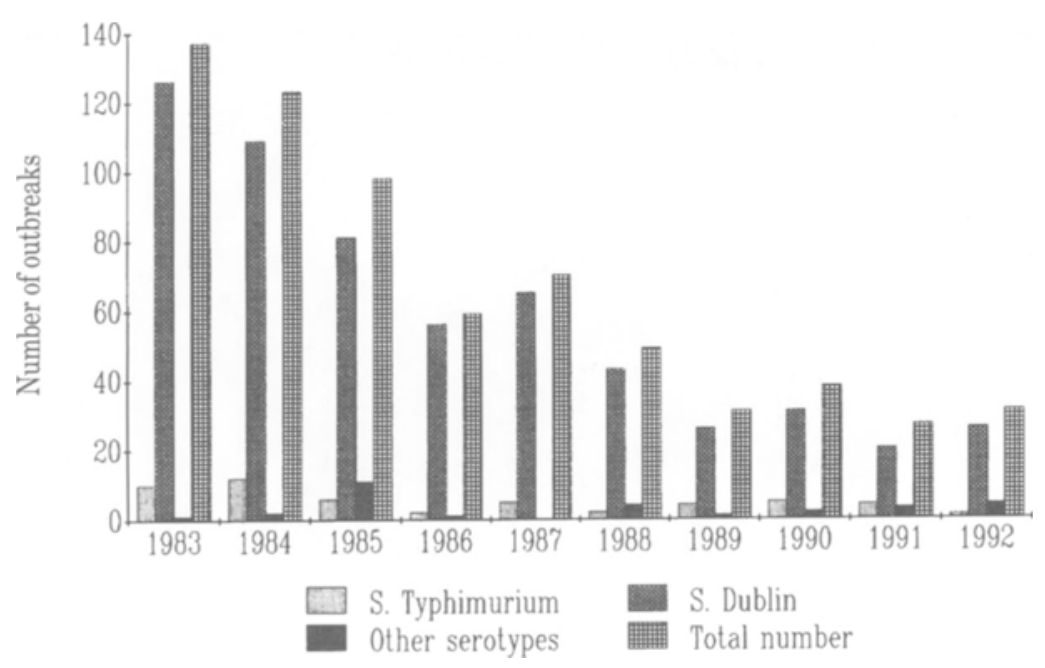

Figure 1. Recorded outbreaks of Salmonella in cattle 1983-1992.

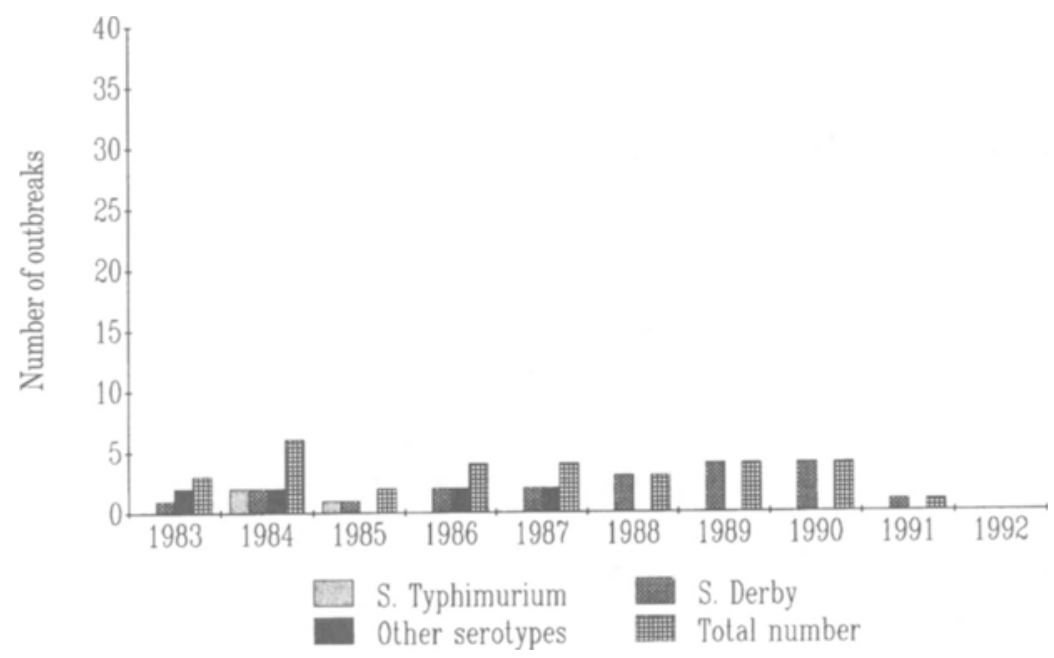

Figure 2. Recorded outbreaks of Salmonella in swine 1983-1992.

number of outbreaks shows a conspicuous decrease, 1746 (1968-1972), 1106 (1973-1977), 1266 (1978-1982) and 760 (1983-1987). However subspecies diarizonae shows an increased number of outbreaks compared with previous periods. The explanation for this can be referred to a study of the incidence of Salmonella in wild snakes in Sweden which was undertaken in 1988. A further analysis of this study is found under "Salmonella in wild animals".

Fifty-six different serotypes were identified in 
Table 2. Serotype distribution of Salmonella outbreaks in animals during 1988-92.

\begin{tabular}{|c|c|c|c|c|c|c|c|}
\hline Serotype & $\begin{array}{c}\text { Last isolation } \\
\text { before } 1988\end{array}$ & 1988 & 1989 & 1990 & 1991 & 1992 & Total \\
\hline S. Abaetetuba & & 1 & & & & & 1 \\
\hline S. Adelaide & & 1 & & & & & 1 \\
\hline S. Agona & 1986 & 1 & & & 5 & 1 & 7 \\
\hline S. Alachua & & & & & & 1 & 1 \\
\hline S. Anatum & 1986 & & & 4 & 2 & 4 & 10 \\
\hline S. Arizonae III & 1986 & 2 & & & 2 & 1 & 5 \\
\hline S. Bardo & & & & & 1 & & 1 \\
\hline S. Bergedorf & & 1 & & & & & 1 \\
\hline S. Bielthoven II & 1984 & & & & & 1 & 1 \\
\hline S. Bovismorbificans & & & 2 & & & 1 & 3 \\
\hline S. Bredeny & 1980 & & & & 1 & & 1 \\
\hline S. Carrau & 1987 & 2 & & 1 & & & 3 \\
\hline S. Derby & 1987 & 3 & 5 & 9 & 1 & & 18 \\
\hline S. Dublin & 1987 & 44 & 26 & 31 & 21 & 26 & 148 \\
\hline S. Duesseldorf & 1985 & & & 1 & & 1 & 2 \\
\hline S. Durban & & 1 & & & & & 1 \\
\hline S. Enteritidis & 1985 & & & 2 & 4 & 3 & 9 \\
\hline S. Florida & & & & & 1 & & 1 \\
\hline S. Give & 1981 & & 2 & & & & 2 \\
\hline S. Hadar & 1980 & & & & 2 & & 2 \\
\hline S. Haifa & 1970 & & & & 1 & & 1 \\
\hline S. Inchpark & & & & 1 & & & 1 \\
\hline S. Infantis & 1986 & & & & 2 & 2 & 4 \\
\hline S. Kiisi & & & & 1 & & & 1 \\
\hline S. Lexington & 1983 & & 1 & & 1 & & 2 \\
\hline S. Livingstone & 1987 & 1 & 1 & 3 & 18 & 8 & 31 \\
\hline S. Makumira II & & 1 & & & & & 1 \\
\hline S. Mbandaka & 1983 & 1 & & & 4 & 1 & 6 \\
\hline S. Meleagridis & 1981 & & 1 & & 1 & & 2 \\
\hline S. Mons & & & & & 1 & & 1 \\
\hline S. Montevideo & 1986 & & 2 & & & & 2 \\
\hline S. Muenchen & 1981 & & 1 & & & & 1 \\
\hline S. Nessziona & & 1 & & & & & 1 \\
\hline S. Newport & 1986 & 1 & & & & & 1 \\
\hline S. Ohio & 1981 & & & & 1 & 1 & 2 \\
\hline S. Oranienburg & 1982 & & 1 & 1 & & & 2 \\
\hline S. Orion & 1981 & & & & & 1 & 1 \\
\hline S. Paratyphi B & 1977 & 1 & & & & & 1 \\
\hline S. Pomona & 1987 & 2 & & & & & 2 \\
\hline S. Rissen & 1979 & & & 1 & 1 & 1 & 3 \\
\hline S. Saintpaul & 1986 & & 1 & & & & 1 \\
\hline S. Sandiego & 1980 & 1 & & & & & 1 \\
\hline S. Schwarzengrund & & & & & & 1 & 1 \\
\hline S. Senftenberg & 1987 & & & 1 & & & 1 \\
\hline S. Sheffield & & & & & 1 & & 1 \\
\hline S. Stanley & 1981 & & & 2 & & & 2 \\
\hline S. Tennessee & 1987 & & 1 & 1 & & 2 & 4 \\
\hline S. Typhimurium & 1987 & 73 & 45 & 46 & 22 & 28 & 214 \\
\hline S. Uno & & & 1 & & & & 1 \\
\hline S. Urbana & 1981 & 2 & & & & & 2 \\
\hline S. Welikade & 1987 & 1 & & & & & 1 \\
\hline S. Weltevreden & 1980 & & & & & 1 & 1 \\
\hline S. Westhampton & & & & 1 & & & 1 \\
\hline S. Worthington & 1981 & & 1 & & & & 1 \\
\hline S. Wil & & & & & 1 & & 1 \\
\hline S. Yoff & & 2 & & & & & 2 \\
\hline Subspecies I & & 2 & & 1 & & 2 & 5 \\
\hline Subspecies II & & 1 & 2 & 1 & 2 & 5 & 11 \\
\hline Subspecies III & & 52 & 2 & 2 & 1 & 2 & 59 \\
\hline Subspecies IV & & 1 & 1 & & & 2 & 4 \\
\hline Not typable & & 2 & & & & & 2 \\
\hline Not typed & & & & & 1 & 1 & 2 \\
\hline Total & & 201 & 96 & 110 & 98 & 97 & 602 \\
\hline
\end{tabular}

$\mathrm{I}=$ enterica, $\mathrm{II}=$ salamae, $\mathrm{III}$ = arizonae or diarizonae, $\mathrm{IV}=$ houtenae. 
animals during 1988-1992. They are listed in Table 2 and the year of isolation is given as well as the year previous to 1988 . Nineteen serotypes, listed in Table 3, had not been isolated in animals in Sweden before. Three of these, S. Alachua, S. Schwarzengrund and $S$. Westhampton were isolated from dogs, 2 orginated from cattle, S. Durban and S. Bovismorbificans, 1 from chicken, $S$. Wil, and 1 from a zoo bird, S. Mons. All the others were isolated from lizards, snakes or tortoises.

Phage typing of $S$. Typhimurium strains isolated from animals is presented in Table 4.

Fig. 4 demonstrates recorded outbreaks of Salmonella in various species during the period 1958-1992.

Salmonella isolated from cattle. The number of reported outbreaks in cattle during the period 1988-1992 was 178 (Tables 5-9). It is a remarkable reduction and the number constitutes only $38 \%$ of the total compared with 1983-1987, when 474 outbreaks were reported (Fig. 4). The most prominent reduction may partly be related to a reduced sam-
Table 3. Salmonella serotypes which have not been isolated in animals in Sweden before 1988 .

\begin{tabular}{lll}
\hline Serotype & $\begin{array}{l}\text { Year of } \\
\text { isolation }\end{array}$ & $\begin{array}{l}\text { Animal } \\
\text { species }\end{array}$ \\
\hline S. Abaetetuba & 1988 & lizard \\
S. Adelaide & 1988 & snake \\
S. Alachua & 1992 & dog \\
S. Bardo & 1991 & tortoise \\
S. Bergedorf & 1989 & snake \\
S. Bovismorbificans & 1989 & cattle \\
S. Durban & 1988 & cattle \\
S. Florida & 1991 & snake \\
S. Inchpark & 1990 & lizard \\
S. Kiisi & 1990 & snake \\
S. Makumira II & 1988 & lizard \\
S. Mons & 1991 & bird (zoo) \\
S. Nessziona & 1988 & tortoise \\
S. Schwarzengrund & 1992 & dog \\
S. Sheffield & 1991 & tortoise \\
S. Uno & 1989 & snake \\
S. Westhampton & 1990 & dog \\
S. Wil & 1991 & chicken \\
S. Yoff & 1988 & snake \\
\hline
\end{tabular}

pling. The number of reported cases has flattened somewhat in the last few years. The variation in the occurrence of Salmonella in

Table 4. Phage typing of Salmonella Typhimurium strains isolated from animals during 1988-92.

\begin{tabular}{|c|c|c|c|c|c|c|c|c|c|c|c|c|}
\hline Species/Phage type & 1 & 2 & 4 & 8 & 9 & 12 & 15 & 22 & NST & NT & $\begin{array}{c}\text { Not } \\
\text { typed }\end{array}$ & Total \\
\hline Cattle & 1 & 3 & & 5 & & & 3 & & 2 & 2 & 1 & 17 \\
\hline Horses & 4 & & & 1 & 1 & 1 & & & 1 & 3 & 1 & 12 \\
\hline Dogs & 1 & & & & & & & & & & & 1 \\
\hline Cats & 7 & & & & 3 & & & & & & & 10 \\
\hline Sheep & & & & & & & & & 1 & 1 & & 2 \\
\hline Foxes & 1 & 1 & & & & & & & & & & 2 \\
\hline Hens \& chickens & 1 & 11 & & & & & 1 & & 1 & 2 & & 16 \\
\hline Ducks & & & & & & & & & 1 & & 1 & 2 \\
\hline Geese & & 1 & & & & & & & & & & 1 \\
\hline Cage birds & & & & 2 & & & & 1 & 6 & 2 & 1 & 12 \\
\hline Pigeons & & & & 9 & & & & & 2 & & & 11 \\
\hline Wild birds & 49 & 3 & 1 & & 51 & & & & 2 & 12 & 5 & 123 \\
\hline Wild mammals & 1 & & & & 1 & & & & & & 2 & 4 \\
\hline Zoo animal & & & & & & & & & 1 & & & 1 \\
\hline Total & 65 & 19 & 1 & 17 & 56 & 1 & 4 & 1 & 17 & 22 & 11 & 214 \\
\hline
\end{tabular}




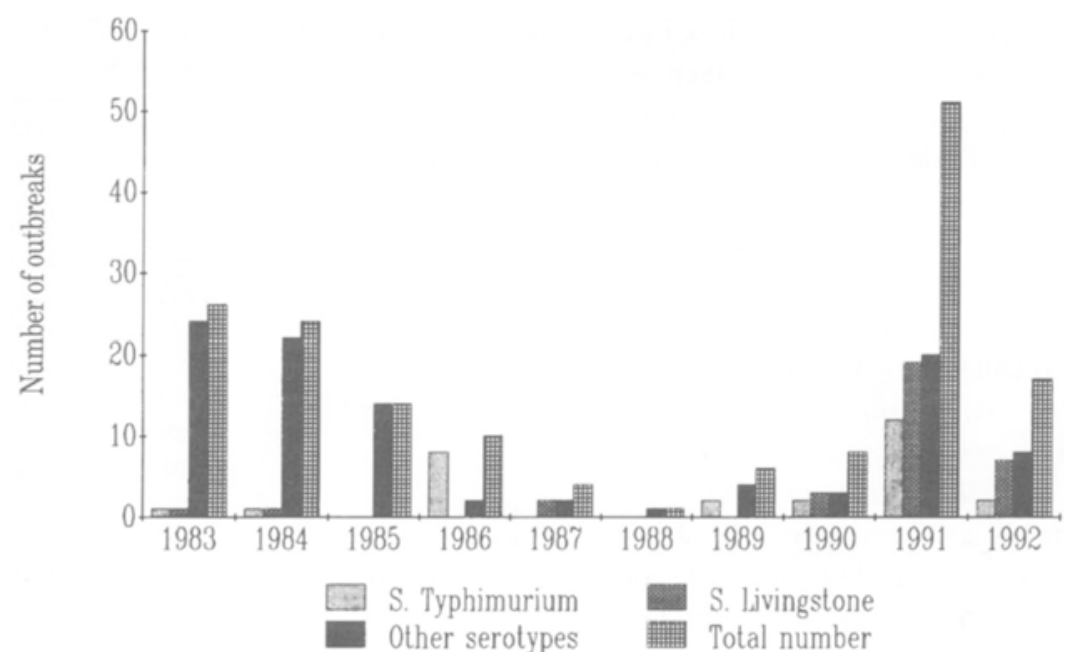

Figure 3. Recorded outbreaks of Salmonella in poultry 1983-1992.

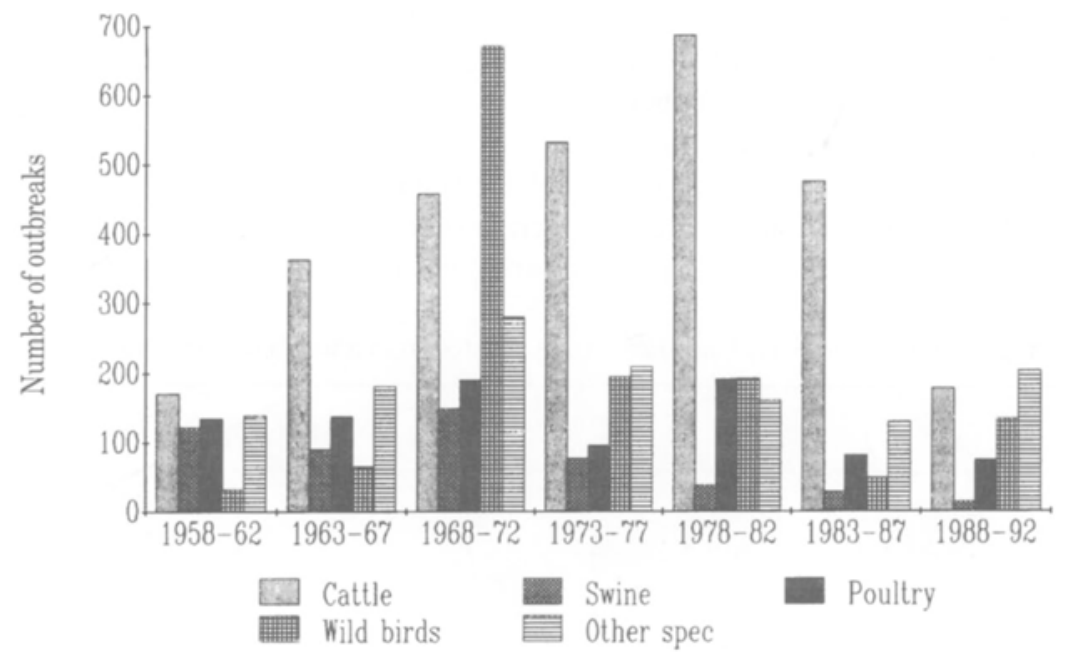

Figure 4. Recorded outbreaks of Salmonella in various species 1958-1992.

cattle during the last 10 years is shown in Fig. 1. During 1983-87 the total number of annual outbreaks varied between 59 and 139 while the corresponding numbers during 1988-1992 varied between 27 and 50 . The most frequent Salmonella serovar found in cattle during
1988-1992 was S. Dublin, 82\% (146). S. Typhimurium was isolated in $10 \%$ (17) and other serotypes in $8 \%$ (15) of the outbreaks (Fig. 1).

Salmonella isolated from swine. During 1988-1992 there were 12 reported out- 
Table 5. Salmonella serotypes isolated from various outbreaks during 1988.

\begin{tabular}{|c|c|c|c|c|c|c|c|c|c|c|c|c|c|}
\hline & 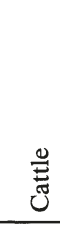 & 䒺 & 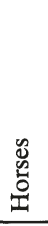 & $\begin{array}{l}\text { 足 } \\
0 \\
\end{array}$ & 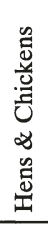 & $\begin{array}{l}\text { U. } \\
\text { रे } \\
\text { c. }\end{array}$ & 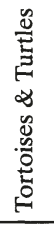 & 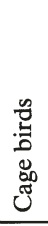 & 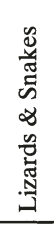 & $\begin{array}{l}\text { 音 } \\
0 \\
0 \\
0\end{array}$ & 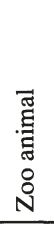 & 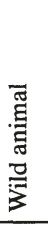 & 焉 \\
\hline S. Abaetetuba & & & & & & & & & 1 & & & & 1 \\
\hline S. Adelaide & & & & & & & & & 1 & & & & 1 \\
\hline S. Agona & & & & & 1 & & & & & & & & 1 \\
\hline S. Arizona III & & & & & & & & & 2 & & & & 2 \\
\hline S. Bergedorf & & & & & & & & & 1 & & & & 1 \\
\hline S. Carrau & & & & & & & & & 2 & & & & 2 \\
\hline S. Derby & & 3 & & & & & & & & & & & 3 \\
\hline S. Dublin & 43 & & & & & & 1 & & & & & & 44 \\
\hline S. Durban & 1 & & & & & & & & & & & & 1 \\
\hline S. Livingstone & & & & 1 & & & & & & & & & 1 \\
\hline S. Makumira & & & & & & & & & 1 & & & & 1 \\
\hline S. Mbandaka & & & & 1 & & & & & & & & & 1 \\
\hline S. Nessziona & & & & & & & 1 & & & & & & 1 \\
\hline S. Newport & & & & & & & & & 1 & & & & 1 \\
\hline S. Parathypi B & & & & & & & 1 & & & & & & 1 \\
\hline S. Pomona & & & & & & & 1 & & 1 & & & & 2 \\
\hline S. Sandiego & 1 & & & & & & & & & & & & 1 \\
\hline S. Typhimurium & 3 & & 5 & & & 2 & & 8 & & 53 & 1 & 1 & 73 \\
\hline S. Urbana & & & & & & & 1 & & 1 & & & & 2 \\
\hline S. Welikade & & & & & & & & & 1 & & & & 1 \\
\hline S. Yoff & & & & & & & & & 2 & & & & 2 \\
\hline Subspecies I & & & & & & & & & 2 & & & & 2 \\
\hline Subspecies II & & & & & & & & & 1 & & & & 1 \\
\hline Subspecies III & & & & & & & 1 & & 51 & & & & 52 \\
\hline Subspecies IV & & & & & & & & & 1 & & & & 1 \\
\hline Not typable & 2 & & & & & & & & & & & & 2 \\
\hline Total & 50 & 3 & 5 & 2 & 1 & 2 & 6 & 8 & 69 & 53 & 1 & 1 & 201 \\
\hline
\end{tabular}

$\mathrm{I}$ = enterica, $\mathrm{II}$ = salamae, $\mathrm{III}$ = arizonae or diarizonae, $\mathrm{IV}=$ houtenae.

breaks in swine (Tables 5-9 and Fig. 2). The corresponding number for the period 19831987 was 19 , which means a reduction of $37 \%$. Fig. 2 shows the recorded outbreaks of Salmonella during 1983-1992. Not a single case was reported in 1992. Salmonella Derby was the only isolated serotype during 1988-1992. The extremely low number of outbreaks lately, indicates that Salmonella infections in swine are not a major problem in Sweden. S. cholerae suis has not been isolated in swine since 1979.

Salmonella isolated from poultry. The number of Salmonella outbreaks in poultry during 1988-1992 is shown in Tables 5-9 and Fig. 3. Besides outbreaks in hens and chickens, the figures also comprise a few cases in geese, ducks and turkeys ( 1 isolation of $S$. Typhimurium in geese in 1989 and 2 in ducks in 
Table 6. Salmonella serotypes isolated from various outbreaks during 1989.

\begin{tabular}{|c|c|c|c|c|c|c|c|c|c|c|c|c|c|c|}
\hline & 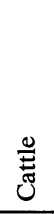 & 莺 & 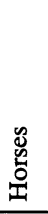 & 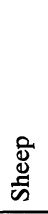 & $\begin{array}{l}0 \\
0 \\
0\end{array}$ & $\stackrel{n}{0}$ & 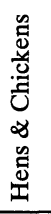 & $\begin{array}{l}\text { U. } \\
\text { J } \\
\text { ర }\end{array}$ & 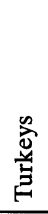 & 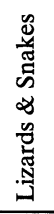 & $\begin{array}{l}\text { 量 } \\
0 \\
0 \\
0\end{array}$ & 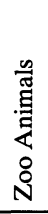 & 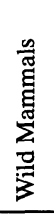 & స్ّ \\
\hline \multicolumn{15}{|l|}{ S. Bovismor- } \\
\hline bificans & 1 & & & & & & & & & & & & 1 & 14 \\
\hline S. Derby & 1 & 4 & & & & & & & & & & & & 5 \\
\hline S. Dublin & 26 & & & & & & & & & & & & & 26 \\
\hline S. Give & & & & & & & & & & & & & 2 & 2 \\
\hline S. Lexington & & & & & & & & & & 1 & & & & 1 \\
\hline S. Livingstone & & & & & 1 & & & & & & & & & 1 \\
\hline S. Meleagridis & & & & & & & 1 & & & & & & & 1 \\
\hline S. Montevideo & & & & & & & & & & 1 & & & 1 & 2 \\
\hline S. Muenchen & & & & & & & & & & 1 & & & & 1 \\
\hline S. Oranienburg & & & & & & & & & & 1 & & & & 1 \\
\hline S. Saintpaul & & & & & 1 & & & & & & & & & 1 \\
\hline S. Tennessee & & & & & & & & & 1 & & & & & 1 \\
\hline S. Typhimuri & 4 & & 3 & 1 & & 2 & 1 & 1 & & 2 & 28 & & 3 & 45 \\
\hline S. Uno & & & & & & & & & & 1 & & & & 1 \\
\hline S. Worthington & & & & & & & & & 1 & & & & & 1 \\
\hline Subspecies II & & & & & & & & & 1 & 1 & & & & 2 \\
\hline Subspecies III & & & & & & & & & & 2 & & & & 2 \\
\hline Subspecies IV & & & & & & & & & & 1 & & & & 1 \\
\hline Total & 32 & 4 & 3 & 1 & 2 & 2 & 2 & 1 & 3 & 11 & 28 & 2 & 5 & 96 \\
\hline
\end{tabular}

$\mathrm{II}=$ salamae, $\mathrm{III}=$ Arizonae or diatizonae, $\mathrm{IV}=$ houtenae .

1992, 3 outbreaks of other serotypes in turkeys in 1989, and 2 in 1991). The number of outbreaks in hens and chicken was continuously falling between 1983 and 1988, only 1 case beeing reported in the latter year. After this year there was a conspicuous rise in the number of isolations with a peak in 1991, when 48 outbreaks were reported. This rise reflects that the poultry industry this year initiated a routine testing program for Salmonella in layer flocks 6-8 weeks prior to slaughter. The testing included approximately $90 \%$ of all layer flocks. Three pooled samples, each containing faeces from 30 individuals, are tested for the occurrence of Salmonella. Another contributing reason for the higher num- ber of outbreaks in 1991 was a Salmonella infection in a breeding flock (the first since 1970s). From this breeding herd S. Typhimurium was spred to 9 broiler herds. As a consequence of the control of infected herds, as well as disinfection of the buildings, the number of new infections rapidly decreased. In 1992 the total number of outbreaks was 15 , which is only $31 \%$ in the peak figures of the year 1991. The most common serotype in poultry during 1988-1992 was S. Livingstone, which comprised $38 \%$ of the total number of outbreaks, while the corresponding figure for S. Typhimurium was $20 \%$. In most countries $S$. Enteritidis is the most common serovar. During the last 5 years only 4 outbreaks 
Table 7. Salmonella serotypes isolated from various outbreaks 1990.

\begin{tabular}{|c|c|c|c|c|c|c|c|c|c|c|c|c|}
\hline & & 点 & 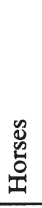 & 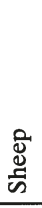 & $\begin{array}{l}0 \\
0 \\
0\end{array}$ & రే & 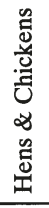 & $\begin{array}{l}0.0 \\
\frac{.}{0} \\
0 \\
0\end{array}$ & 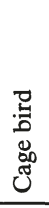 & 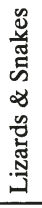 & $\begin{array}{l}\text { 递 } \\
0 \\
0 \\
3\end{array}$ & ثేّ \\
\hline S. Anatum & & & & & 3 & & 1 & & & & & 4 \\
\hline S. Carrau & & & & & & & & & & & 1 & 1 \\
\hline S. Derby & & 4 & & & 2 & & 1 & & & 2 & & 9 \\
\hline S. Dublin & 31 & & & & & & & & & & & 31 \\
\hline S. Duesseldorf & 1 & & & & & & & & & & & 1 \\
\hline S. Enteritidis & & & & & & 1 & 1 & & & & & 2 \\
\hline S. Inchpark & & & & & & & & & & & 1 & 1 \\
\hline S. Kiisi & & & & & & & & & & & 1 & 1 \\
\hline S. Livingstone & & & & & 1 & & 2 & & & & & 3 \\
\hline S. Oranienburg & & & & & & & & & & 1 & & 1 \\
\hline S. Rissen & & & & & 1 & & & & & & & 1 \\
\hline S. Senftenberg & 1 & & & & & & & & & & & 1 \\
\hline S. Stanley & & & & & 2 & & & & & & & 2 \\
\hline S. Tennessee & & & & & & & 1 & & & & & 1 \\
\hline S. Typhimurium & 5 & & 3 & 1 & 1 & 6 & 2 & & 1 & & 27 & 46 \\
\hline S. Westhampton & & & & & 1 & & & & & & & 1 \\
\hline Subspecies I & & & & & 1 & & & & & & & 1 \\
\hline Subspecies II & & & & & & & & 1 & & & & 1 \\
\hline Subspecies III & & & & & & & & & & 2 & & 2 \\
\hline Total & 38 & 4 & 3 & 1 & 12 & 7 & 8 & 1 & 1 & 8 & 27 & 110 \\
\hline
\end{tabular}

$\mathrm{I}$ = enterica, $\mathrm{II}$ = salamae, $\mathrm{III}$ = arizonae or diarizonae.

caused by this serotype have been reported in Sweden.

Salmonella in wild animals. There was a large variation in the number of outbreaks of Salmonella in wild birds. For instance the incidence in 1988 was 53 cases, while the corresponding figure for 1991 was only 3. This may reflect real variations in Salmonella occurrence but may also be a result of changes in public concern. Thus dead birds found in the environment are infrequently brought to the veterinary laboratories for necropsy. We have also recorded that in cold winters there is an increased occurrence of outbreaks in wild birds. During 1988-92 there were 133 isola- tions of Salmonella in wild birds. All of these isolations were $S$. Typhimurium, mainly phagetypes 1 and 9 . The birds most commonly affected were finches, siskins and tits. Nine pigeons were shown to be infected by $S$. Typhimurium phagetype 8 . Interestingly, the predominant phagetype isolated from pigeons before 1982 was $6 \mathrm{~b}$ as observed by Hurvell et al. (1969), Gunnarsson et al. (1974), Sandstedt et al. (1980) and Mårtenson et al. (1984). During the period 1983-87, 2 isolations of phagetype $6 \mathrm{~b}$ and 3 of phagetype 8 were found in pigeons (Eld et al, 1991). The reason for the presence of these phagetypes in pigeons and the change of predominant phagetype lately is not known. 
Table 8. Salmonella serotypes isolated from various outbreaks during 1991.

\begin{tabular}{|c|c|c|c|c|c|c|c|c|c|c|c|c|c|}
\hline & 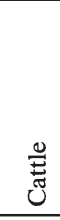 & $\stackrel{0}{\tilde{E}}$ & 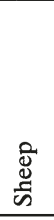 & $\overrightarrow{\tilde{U}}$ & 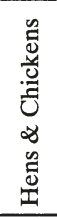 & $\begin{array}{l}\text { 恿 } \\
\text { 恶 } \\
\end{array}$ & 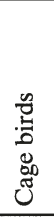 & 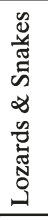 & 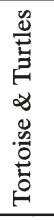 & $\begin{array}{l}0 \\
\frac{0}{2} \\
\frac{0}{0} \\
0 \\
0\end{array}$ & $\begin{array}{l}0 \\
0 \\
0 \\
0 \\
0 \\
N\end{array}$ & 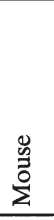 & 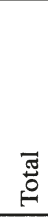 \\
\hline S. Agona & & & & & 2 & 2 & & & & & 1 & & 5 \\
\hline S. Anatum & & & & & 2 & & & & & & & & 2 \\
\hline S. Arizonae III & & & 1 & & & & & & 1 & & & & 2 \\
\hline S. Bardo & & & & & & & & 1 & & & & & 1 \\
\hline S. Bredeny & & & & & & & & & & & 1 & & 1 \\
\hline S. Derby & & 1 & & & & & & & & & & & 1 \\
\hline S. Dublin & 20 & & & 1 & & & & & & & & & 21 \\
\hline S. Enteritidis & & & & & 2 & & 1 & & & & & 1 & 4 \\
\hline S. Florida & & & & & & & & & 1 & & & & 1 \\
\hline S. Hadar & & & & & 2 & & & & & & & & 2 \\
\hline S. Haifa & & & & & 1 & & & & & & & & 1 \\
\hline S. Infantis & & & & & 2 & & & & & & & & 2 \\
\hline S. Lexington & & & & & 1 & & & & & & & & 1 \\
\hline S. Livingstone & & & & & 18 & & & & & & & & 18 \\
\hline S. Mbandaka & & & & & 4 & & & & & & & & 4 \\
\hline S. Meleagridis & & & & & 1 & & & & & & & & 1 \\
\hline S. Mons & & & & & & & & & & & 1 & & 1 \\
\hline S. Ohio & 1 & & & & & & & & & & & & 1 \\
\hline S. Rissen & 1 & & & & & & & & & & & & 1 \\
\hline S. Sheffield & & & & & & & & 1 & & & & & 1 \\
\hline S. Typhimurium & 4 & & & & 12 & & 3 & & & 3 & & & 22 \\
\hline S. Wil & & & & & 1 & & & & & & & & 1 \\
\hline Subspecies II & & & & & & & & 2 & & & & & 2 \\
\hline Subspecies III & & & & & & & & & 1 & & & & 1 \\
\hline Not typed & 1 & & & & & & & & & & & & 1 \\
\hline Total & 27 & 1 & 1 & 1 & 48 & 2 & 4 & 4 & 3 & 3 & 3 & 1 & 98 \\
\hline
\end{tabular}

$\mathrm{II}=$ salamae, $\mathrm{III}=$ arizonae or diarizonae.

During 1988 a study on the occurrence of Salmonella in wild snakes was carried out by the Department of Zoology at Uppsala University. Material collected were brought to our laboratory. A surprisingly high prevalence of Salmonella infected animals was found. Fortysix snakes or $38 \%$ of the examined animals were shown to be infected by Salmonella. The isolated serotypes were mainly of the subspecies diarizonae (43 cases).

In wild mammals very few isolations of Salmonella were identified. In 1989 and 19912 small rodents caught in areas where outbreaks of Salmonella had been diagnosed in herds of cattle or poultry, showed the same serotype as in the herds (S. Bovismorbificans and S. Enteritidis respectively). This demonstrates the well-known fact that wild rodents can be an important vector and reservoir of Salmonella. S. Montevideo was isolated from a moose and S. Typhimurium from a roedeer and a fox in 1989.

Salmonella in zoo animals. Very few cases of Salmonella were reported from zoo 
Table 9. Salmonella serotypes isolated from various outbreaks during 1992.

\begin{tabular}{|c|c|c|c|c|c|c|c|c|c|c|c|}
\hline & $\begin{array}{l}\stackrel{\Perp}{E} \\
\text { Uू } \\
\end{array}$ & 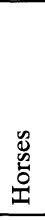 & $\begin{array}{l}\text { 品 } \\
\stackrel{0}{0}\end{array}$ & in & 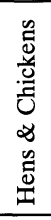 & 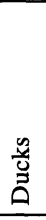 & 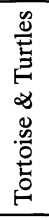 & 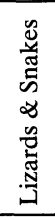 & 氮 & $\begin{array}{l}\frac{n}{5} \\
0 \\
0 \\
0\end{array}$ & 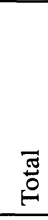 \\
\hline S. Agona & 1 & & & & & & & & & & 1 \\
\hline S. Alachua & & & 1 & & & & & & & & 1 \\
\hline S. Anatum & & & 2 & & 2 & & & & & & 4 \\
\hline S. Arizonae & & & & & & & & 1 & & & 1 \\
\hline S. Bielthoven & & & & & & & 1 & & & & 1 \\
\hline S. Bovismorbicicans & & & & & & & & 1 & & & 1 \\
\hline S. Dublin & 26 & & & & & & & & & & 26 \\
\hline S. Duesseldorf & & & & & 1 & & & & & & 1 \\
\hline S. Enteritidis & 1 & 1 & & & 1 & & & & & & 3 \\
\hline S. Infantis & & & & & 2 & & & & & & 2 \\
\hline S. Livingstone & & & & & 8 & & & & & & 8 \\
\hline S. Mbandaka & 1 & & & & & & & & & & 1 \\
\hline S. Ohio & & & & & & & & & 1 & & 1 \\
\hline S. Orion & 1 & & & & & & & & & & 1 \\
\hline S. Rissen & & & & & 1 & & & & & & 1 \\
\hline S. Schwartzengrund & & & 1 & & & & & & & & 1 \\
\hline S. Tennessee & & & 2 & & & & & & & & 2 \\
\hline S. Typhimurium & 1 & 1 & & 2 & & 2 & & & & 22 & 28 \\
\hline S. Weltevreden & & & 1 & & & & & & & & 1 \\
\hline Subspecies I & & & & & & & 1 & 1 & & & 2 \\
\hline Subspecies II & & & & & & & 2 & 3 & & & 5 \\
\hline Subspecies III & & & & & & & & 2 & & & 2 \\
\hline Subspecies IV & & & & & & & & 2 & & & 2 \\
\hline Not typed & & & 1 & & & & & & & & 1 \\
\hline Total & 31 & 2 & 8 & 2 & 15 & 2 & 4 & 10 & 1 & 22 & 97 \\
\hline
\end{tabular}

$\mathrm{I}$ = Enterica, $\mathrm{II}$ = salamae, III = arizonae or diarizonae, IV = houtenae.

animals. In 1988, S. Typhimurium was isolated from an elephant. In 19891 outbreak of $S$. give was detected in tenrecs and 1 armadillo. S. Agona, S. Bredeny and S. Mons were isolated from 3 birds in 1991. A study on the prevalence of Salmonella in snakes in captivity was performed simultaneously with the mentioned study in wild snakes. Of 22 examined snakes 12 , or $54 \%$, were found to be infected by Salmonella, 3 of them even with 2 different serotypes. The isolated serotypes were S. Pomona, S. Adelaide, S. Newport, S.
Welikade and subspecies diarizonae. These observations agree with the results of the study of wild snakes, which indicates that Salmonella is quite a common bacterium in snakes.

Salmonella in pet animals. In dogs and cats the number of Salmonella isolations shows a strong variation over time. For instance, there were 12 outbreaks of Salmonella reported in dogs in 1990, while in 1991 not a single case occurred. During the period 1988- 
Table 10a. Salmonella isolated during 1988-1992 in connection with import of feed stuffs of animal origin.

\begin{tabular}{|c|c|c|c|c|c|c|}
\hline Feed stuff & $\begin{array}{l}\text { Country } \\
\text { of origin }\end{array}$ & $\begin{array}{c}\text { No. of } \\
\text { consignments } \\
\text { investigated }\end{array}$ & $\begin{array}{c}\text { No. of } \\
\text { samples } \\
\text { examined }\end{array}$ & $\begin{array}{l}\text { No. of consign- } \\
\text { ments with } \\
\text { Salmonella }\end{array}$ & $\begin{array}{c}\text { No. of } \\
\text { samples with } \\
\text { Salmonella }\end{array}$ & $\begin{array}{c}\text { Salmonella } \\
\text { type * }\end{array}$ \\
\hline $\begin{array}{l}\text { Meat and } \\
\text { bone meal }\end{array}$ & $\begin{array}{l}\text { Denmark } \\
\text { Finland } \\
\text { France } \\
\text { West Germany } \\
(1988-1989)\end{array}$ & $\begin{array}{r}430 \\
27 \\
1 \\
1\end{array}$ & $\begin{array}{r}6453 \\
269 \\
6 \\
5\end{array}$ & $\begin{array}{r}28 \\
0 \\
0 \\
0\end{array}$ & $\begin{array}{r}60 \\
0 \\
0 \\
0\end{array}$ & 1) \\
\hline Meat meal & $\begin{array}{l}\text { France } \\
\text { Denmark } \\
\text { Germany } \\
(1990-1992) \\
\text { West Germany } \\
(1988-1989) \\
\text { Belgium } \\
\text { Schweiz } \\
\text { Holland } \\
\text { Finland }\end{array}$ & $\begin{array}{r}234 \\
128 \\
42 \\
\\
18 \\
\\
45 \\
3 \\
1 \\
1\end{array}$ & $\begin{array}{r}2502 \\
2107 \\
782 \\
\\
553 \\
\\
416 \\
30 \\
15 \\
9\end{array}$ & $\begin{array}{r}33 \\
2 \\
6 \\
\\
7 \\
\\
\\
8 \\
1 \\
1 \\
0\end{array}$ & $\begin{array}{r}88 \\
3 \\
44 \\
\\
32 \\
\\
\\
14 \\
1 \\
2 \\
0\end{array}$ & $\begin{array}{l}\text { 2) } \\
\text { 3) } \\
4) \\
\text { 5) } \\
\text { 6) } \\
\text { 7) } \\
8)\end{array}$ \\
\hline Feather meal & $\begin{array}{l}\text { Holland } \\
\text { West Germany } \\
(1988-1989) \\
\text { Germany } \\
(1990-1992) \\
\text { France }\end{array}$ & $\begin{array}{r}145 \\
70 \\
50 \\
\\
8\end{array}$ & $\begin{array}{r}1877 \\
659 \\
574 \\
146\end{array}$ & $\begin{array}{r}15 \\
14 \\
7 \\
\\
\\
0\end{array}$ & $\begin{array}{r}34 \\
32 \\
17 \\
0\end{array}$ & $\begin{array}{r}9) \\
10) \\
11)\end{array}$ \\
\hline Graves meal & $\begin{array}{l}\text { Germany } \\
(1990-1992) \\
\text { West Germany } \\
(1988-1989) \\
\text { Belgium }\end{array}$ & $\begin{array}{l}46 \\
9 \\
5\end{array}$ & $\begin{array}{l}717 \\
183 \\
60\end{array}$ & $\begin{array}{l}2 \\
2 \\
0\end{array}$ & $\begin{array}{l}6 \\
5 \\
0\end{array}$ & $\begin{array}{l}\text { 12) } \\
13)\end{array}$ \\
\hline $\begin{array}{l}\text { Protein- } \\
\text { powder }\end{array}$ & Denmark & 11 & 292 & 0 & 0 & \\
\hline Fish meal & $\begin{array}{l}\text { Chile } \\
\text { France } \\
\text { Denmark } \\
\text { Norway } \\
\text { Island } \\
\text { the Farao Islands }\end{array}$ & $\begin{array}{r}1 \\
9 \\
2 \\
14 \\
1 \\
1\end{array}$ & $\begin{array}{r}244 \\
92 \\
47 \\
30 \\
5 \\
1\end{array}$ & $\begin{array}{l}1 \\
0 \\
0 \\
0 \\
0 \\
0\end{array}$ & $\begin{array}{l}1 \\
0 \\
0 \\
0 \\
0 \\
0\end{array}$ & 14) \\
\hline Bloodmeal & $\begin{array}{l}\text { Germany } \\
(1990-1992) \\
\text { West Germany } \\
(1988-1989) \\
\text { Denmark }\end{array}$ & $\begin{array}{l}11 \\
5 \\
2\end{array}$ & $\begin{array}{l}114 \\
95 \\
61\end{array}$ & $\begin{array}{l}2 \\
3 \\
0\end{array}$ & $\begin{array}{l}10 \\
4 \\
0\end{array}$ & $\begin{array}{l}\text { 15) } \\
16)\end{array}$ \\
\hline Bone meal & $\begin{array}{l}\text { Germany } \\
(1990-1992) \\
\text { Belgium } \\
\text { West Germany } \\
(1988-1989) \\
\text { Denmark }\end{array}$ & $\begin{array}{r}10 \\
11 \\
7 \\
6\end{array}$ & $\begin{array}{l}96 \\
70 \\
56 \\
\\
20\end{array}$ & $\begin{array}{l}2 \\
1 \\
0 \\
0\end{array}$ & $\begin{array}{l}2 \\
6 \\
0 \\
0\end{array}$ & $\begin{array}{l}\text { 17) } \\
18)\end{array}$ \\
\hline $\begin{array}{l}\text { Meat broth } \\
\text { Clam meal } \\
\text { Milk powder } \\
\text { Other (e.g. } \\
\text { flavor addi- } \\
\text { tive for } \\
\text { petfood) }\end{array}$ & $\begin{array}{l}\text { France } \\
\text { Germany } \\
(1990-1992) \\
\text { USA } \\
\text { England } \\
\text { Sovjetunion } \\
\text { Total }\end{array}$ & $\begin{array}{r}18 \\
2 \\
\\
1 \\
4 \\
1 \\
1386\end{array}$ & $\begin{array}{r}266 \\
34 \\
\\
10 \\
4 \\
1 \\
18930\end{array}$ & $\begin{array}{r}1 \\
0 \\
1 \\
0 \\
0 \\
137\end{array}$ & $\begin{array}{r}1 \\
0 \\
\\
1 \\
0 \\
0 \\
363\end{array}$ & 20) \\
\hline
\end{tabular}

* The number corresponds to the group of serotypes listed in Table $10 \mathrm{~b}$. 
Table 10b: Salmonella serotypes isolated during 1988-1992 from imports of feed stuffs of animal origin.

\begin{tabular}{|c|c|c|c|}
\hline Group & Serotype & Group & Serotype \\
\hline \multirow[t]{11}{*}{ 1) } & \multirow{11}{*}{$\begin{array}{l}\text { S. Montevideo (15) } \\
\text { S. Senftenberg (10) } \\
\text { S. Anatum (8) } \\
\text { S. Infantis (7) } \\
\text { S. Tennessee (7) } \\
\text { S. Thomasville (4) } \\
\text { S. Schleissheim (3) } \\
\text { S. Orion (2) } \\
\text { S. Typhi murium O4, phage type } 1(1) \\
\text { S. Typhi murium, phage type } 1 \text { (1) } \\
\text { S. Cubana (1) } \\
\text { S. Mbandaka (1) }\end{array}$} & 7) & S. Give (1) \\
\hline & & 8) & S. Heidelberg (1) \\
\hline & & & S. Subsp $I=O 4,5: r:-(1)$ \\
\hline & & 9) & S. Bredeney (7) \\
\hline & & & S. London (7) \\
\hline & & & S. Montevideo (7) \\
\hline & & & S. Subsp I:O4,5:r:- (3) \\
\hline & & & S. Heidelberg (2) \\
\hline & & & S. Senftenberg (2) \\
\hline & & & S. Blockley (1) \\
\hline & & & S. Clackamas (1) \\
\hline \multirow{21}{*}{ 2) } & & & S. Dublin (1) \\
\hline & $\begin{array}{l}\text { S. Tillburg (19) } \\
\text { S. Livingstone (8) }\end{array}$ & & S. Enteritidis, phagetype 8 (1) \\
\hline & S. Senftenberg (8) & & S. Kambok (1) \\
\hline & S. Give (6) & & S. Typhi murium $O-4 N T(1)$ \\
\hline & S. Ohio (6) & 10) & S. Anatum (11) \\
\hline & S. Typhi murium (6) & & S. Montevideo (7) \\
\hline & S. Anatum (4) & & $S$. Orion + montevideo (4) \\
\hline & S. Bredeney (4) & & S. Senftenberg (3) \\
\hline & S. Thomasville (4) & & S. Natal (2) \\
\hline & S. Mons (4) & & S. Tennessee (2) \\
\hline & S. Goldcoast (3) & & S. Binza (1) \\
\hline & S. Rissen (3) & & S. Bredeney (1) \\
\hline & S. London (2) & & S. Mbandaka (1) \\
\hline & S. Schwartzengrund (2) & 11) & S. Anatum (6) \\
\hline & S. Subsp I = 4:I,z28:- (2) & & S. Oakam (5) \\
\hline & S. Brazzaville (1) & & S. Mbandaka (3) \\
\hline & S. CO-group (1) & & S. Subsp I:O3,10,15:eh:- (1) \\
\hline & S. EO-group (1) & & S. Subsp I=O6,7:- (1) \\
\hline & S. Hillington (1) & & $S$. Worthington (1) \\
\hline & $\begin{array}{l}\text { S. Montevideo (1) } \\
\text { S. Othamarschen (1) }\end{array}$ & 12) & S. Give (2) \\
\hline & S. Westhampton (1) & & S. Subsp $I=6,7(2)$ \\
\hline 3) & $\begin{array}{l}\text { S. Anatum (1) } \\
\text { S. Infantis (2) }\end{array}$ & & $\begin{array}{l}\text { S. Montevideo (1) } \\
\text { S. Subsp I=0,7:- (1) }\end{array}$ \\
\hline \multirow{7}{*}{ 4) } & \multirow{7}{*}{$\begin{array}{l}\text { S. Montevideo (13) } \\
\text { S. Orion, variant 3, } \\
\text { S. Ohio (7) } \\
\text { S. Urbana (4) } \\
\text { S. Tennessee (3) } \\
\text { S. Bredeney (2) } \\
\text { S. Amager (2) } \\
\text { S. 6,8:eh- (1) }\end{array}$} & 13) & S. Ohio (3) \\
\hline & & & $\begin{array}{l}\text { S. Leopoldville (1) } \\
\text { S. Montevideo (1) }\end{array}$ \\
\hline & & 14) & S. Senftenberg (1) \\
\hline & & 17) & \\
\hline & & 15) & $\begin{array}{l}\text { S. Infantis (2) } \\
\text { S. Beitri (l) }\end{array}$ \\
\hline & & & $\begin{array}{l}\text { S. Bettrn (1) } \\
\text { S. Donna }(1)\end{array}$ \\
\hline & & & $\begin{array}{l}\text { S. Donna (1) } \\
\text { S. Havana (1) }\end{array}$ \\
\hline \multirow[t]{10}{*}{ 5) } & \multirow{10}{*}{$\begin{array}{l}\text { S. Thomasville (11) } \\
\text { S. Bredeney (6) } \\
\text { S. Montevideo (4) } \\
\text { S. Tillburg (3) } \\
\text { S. Livingstone (2) } \\
\text { S. Senftenberg (2) } \\
\text { S. BO-group (1) } \\
\text { S. Give (1) } \\
\text { S. Lexington (1) } \\
\text { S. Urbana (1) }\end{array}$} & & S. Montevideo (1) \\
\hline & & & S. Müenster (1) \\
\hline & & & S. Ohio (1) \\
\hline & & & S. Urbana (1) \\
\hline & & & S. Westhampton (1) \\
\hline & & 16) & S. Montevideo (2) \\
\hline & & & S. Typhi murium $0-4,5$ (1) \\
\hline & & & S. Typhi murium NST (1) \\
\hline & & 17) & S. Bareilly (1) \\
\hline & & 17) & S. Senftenberg (1) \\
\hline \multirow{8}{*}{ 6) } & \multirow{8}{*}{$\begin{array}{l}\text { S. Isangi (5) } \\
\text { S. Anatum (3) } \\
\text { S. Oranienburg (1) } \\
\text { S. Montevideo (1) } \\
\text { S. Sinstorf (1) } \\
\text { S. London (1) } \\
\text { S. Subsp (1) } \\
\text { S. Kapemba (1) }\end{array}$} & & \\
\hline & & 18) & S. Livingstone (6) \\
\hline & & 19) & S. Goldcoast (1) \\
\hline & & & \\
\hline & & 20) & S. Anatum (1) \\
\hline & & & \\
\hline & & & \\
\hline & & & \\
\hline
\end{tabular}


Table 11. Salmonella found in meat meal from Swedish plants during the years 1988-1992.

\begin{tabular}{|c|c|c|c|c|c|}
\hline \multirow{2}{*}{$\begin{array}{l}\text { Meat meal } \\
\text { producing plant }\end{array}$} & \multirow[b]{2}{*}{1988} & \multicolumn{2}{|r|}{ Year } & \multirow[b]{2}{*}{1991} & \multirow[b]{2}{*}{1992} \\
\hline & & 1989 & 1990 & & \\
\hline Stenstorp & $\begin{array}{l}\text { S. Livingstone } \\
\text { S. Infantis }\end{array}$ & - & $\begin{array}{l}\text { S. Senftenberg (7) } \\
\text { S. Westhampton }\end{array}$ & S. Senftenberg (5) & - \\
\hline Krutmöllan & S. Livingstone & - & S. Senftenberg & S. Mbandaka & - \\
\hline Kristianstad & $\begin{array}{l}\text { S. Infantis } \\
\text { S. Subsp }\end{array}$ & - & S. Anatum & - & - \\
\hline Stidsvig & - & S. Hato & $\begin{array}{l}\text { S. Montevideo (2) } \\
\text { S. Braenderup } \\
\text { S. Georgia }\end{array}$ & $\begin{array}{l}\text { S. Mbandaka } \\
\text { S. Give } \\
\text { S. Derby }\end{array}$ & $\begin{array}{l}\text { S. Agona } \\
\text { S. Mbandaka }\end{array}$ \\
\hline Kil & - & - & S. Senftenberg & - & - \\
\hline
\end{tabular}

1992, 24 outbreaks of 13 different serotypes were recorded in dogs. There were 13 outbreaks in cats during the same period. Ten of these cases were serotype S.Typhimurium, which probably reflects the fact that cats often catch wild birds, which may have been infected by this serovar. The number of outbreaks of Salmonella in lizards and snakes during 1988-1992 was 47 . The corresponding number for the preceding period (1983-1987) was 63 . This reduction of outbreaks may be explained by the fact that in December 1987 a short period of more liberal importation regulations had come to an end. There were 14 Salmonella isolations in turtles and tortoises during 1988-1992, and the corresponding figure for cage birds was 13 . These numbers were about the same as during the preceding 5-year-period (16 and 15 respectively).

\section{Salmonella in feedstuffs}

Salmonella isolated in animal feed stuffs. Imports of ready-mixed feed for cloven-footed animals or raw materials that contain animal products have to be licenced by SBA. Only feed of animal origin that has undergone a heat treatment is allowed for import. Samples of the lot are collected in the exporting country by a surveillance company and sent to the NVI for bacteriological examination. If Salmonella bacteria are detected the lot will not be allowed into Sweden. Other compound feeds (mostly pet food) have to be examined for Salmonella in the exporting country. A veterinary declaration of absence of Salmonella in the feed is required before it is imported into Sweden.

The results of investigations of imported feed raw materials of animal origin performed during 1988-1992 are listed in Table 10a \& 10b. Compared with the previous 5-year period, the number of consignments and samples investigated had increased. Salmonella was isolated from $9.9 \%$ of the consignments during the last period, which is a slight increase in comparison with the previous 5-year period (8.6\%).

Testing of domestically produced meat meal, sampled from 1988 to 1992, showed Salmonella contamination on several occasions, as indicated in Table 11. The number of samples where Salmonella could be isolated was slightly decreased compared with the previ- 
Table 12. Salmonella isolated from feed stuffs and feed processing plants in Sweden during 1988-1992. Sampled feeds of animal origin is mainly originating from lots intended for import to Sweden (see Table 10a and b).

\begin{tabular}{|c|c|c|c|c|}
\hline \multirow{2}{*}{$\begin{array}{l}\text { Salmonella } \\
\text { serotypes }\end{array}$} & \multicolumn{2}{|c|}{ Raw materials } & \multirow{2}{*}{$\begin{array}{l}\text { Dust and } \\
\text { scrapings } \\
\text { from feed mills }\end{array}$} & \multirow[b]{2}{*}{ Compound feeds } \\
\hline & $\begin{array}{l}\text { Vegetable } \\
\text { feeds }\end{array}$ & $\begin{array}{c}\text { Feeds of } \\
\text { animal origin }\end{array}$ & & \\
\hline S. Agona & & $3^{1) 6)^{*}}$ & 10 & 1 \\
\hline S. Agona + A. Oranienburg & & $1^{6)}$ & & \\
\hline S. Albanyl & & & 3 & \\
\hline S. Amager & & $2^{1)}$ & & \\
\hline S. Amsterdam & & & 1 & \\
\hline S. Anatum & & $\left.34^{1)-3)} 11\right)$ & 18 & 1 \\
\hline S. Azteka & & & 1 & \\
\hline S. Bareilly & & $1^{2)}$ & & \\
\hline S. Bere & & & 1 & \\
\hline S. Beitri & & $1^{10)}$ & & \\
\hline S. Bergen & 17) & & & \\
\hline S. Blockley & & $1^{3)}$ & & \\
\hline S. Bovis morbificans & & $1^{1)}$ & 2 & \\
\hline S. BO-group & & $1^{1)}$ & & \\
\hline S. Braenderup & & $1^{1)}$ & & \\
\hline S. Brazzaville & & $1^{1)}$ & 1 & \\
\hline S. Bredeney & $2^{5)}$ & 191)3) & 2 & \\
\hline S. California & & & 2 & \\
\hline S. Clackamas & & $1^{3)}$ & & \\
\hline S. CO-group & & $1^{1)}$ & 2 & \\
\hline S. Cubana & $5^{5) 9)}$ & $1^{1)}$ & 48 & 1 \\
\hline S. Derby & & $1^{4)}$ & & \\
\hline S. Donna & & $1^{10)}$ & & \\
\hline S. Dublin & & $1^{3)}$ & & \\
\hline S. Düsseldorf & & & 2 & \\
\hline S. Enteritidis, & & & & \\
\hline phage type 8 & & $1^{3)}$ & & \\
\hline$S . E O$-group & & $1^{1)}$ & & \\
\hline S. Gabon & & & 1 & \\
\hline S. Georgia & & $1^{1)}$ & & \\
\hline S. Give & & $10^{1) 4)}$ & 1 & \\
\hline S. Goldcoast & & $4^{1)}$ & & \\
\hline S. Hadar & & & 1 & \\
\hline S. Havana & $7^{5) 9)}$ & $1^{10)}$ & 7 & \\
\hline S. Heidelberg & & $3^{1) 3)}$ & & \\
\hline S. Hillington & & $1^{1)}$ & & \\
\hline S. Ibadan & & & 1 & \\
\hline S. Infantis & $1^{5)}$ & $11^{1) 2) 10)}$ & 13 & \\
\hline S. Isangi & & $5^{1)}$ & & \\
\hline S. Jerusalem & $1^{5)}$ & & 2 & \\
\hline S. Kambok & & $1^{3)}$ & & \\
\hline S. Kapemba & & $1^{1)}$ & & \\
\hline S. Kiambu & & & 1 & \\
\hline S. Kingston & $2^{5)}$ & & 1 & \\
\hline S. Kentucky & $1^{5)}$ & & & \\
\hline
\end{tabular}


Table 12 (continued)

\begin{tabular}{|c|c|c|c|c|}
\hline \multirow{2}{*}{$\begin{array}{l}\text { Salmonella } \\
\text { serotypes }\end{array}$} & \multicolumn{2}{|c|}{ Raw materials } & \multirow{2}{*}{$\begin{array}{c}\text { Dust and } \\
\text { scrapings } \\
\text { from feed mills }\end{array}$} & \multirow[b]{2}{*}{ Compound feeds } \\
\hline & $\begin{array}{l}\text { Vegetable } \\
\text { feeds }\end{array}$ & $\begin{array}{c}\text { Feeds of } \\
\text { animal origin }\end{array}$ & & \\
\hline S. Kunduchi & & & 1 & \\
\hline S. Leopoldville & & $1^{4)}$ & & \\
\hline S. Lexington & & $25^{1) 6)}$ & 1 & \\
\hline S. Livingstone & 1) & $16^{1) 2)}$ & 26 & 9 \\
\hline S. Llandloff & & & 1 & \\
\hline S. London & & $10^{1) 3)}$ & & \\
\hline S. Meleagridis & & & 1 & \\
\hline S. Molade & & & 1 & \\
\hline S. Mbandaka & $3^{5) 8)}$ & $7^{1)-3)}$ & 12 & \\
\hline S. Mons & & $4^{1)}$ & & \\
\hline S. Montevideo & $1^{1^{2)}}$ & $\left.58^{1)-4)} 10\right)$ & 6 & \\
\hline S. Müenster & & $1^{10)}$ & 1 & \\
\hline S. Newport & & & 1 & 9 \\
\hline S. Oakam & & $5^{3)}$ & & \\
\hline S. Ohio & $2^{12)}$ & 171)4) 10) & 38 & \\
\hline S. Oranienburg & & $13^{1) 6)}$ & & \\
\hline S. Orion & & 141) & & \\
\hline$S$. Orion $+S$. Montevideo & & $4^{3)}$ & & \\
\hline S. Othamarschen & & $1^{1)}$ & & \\
\hline S. Pomona & & & 1 & \\
\hline S. Rissen & $10^{5)}$ & $3^{1)}$ & & 2 \\
\hline S. Ruiru & & & 1 & \\
\hline S. Schleissheim & & $3^{2)}$ & & \\
\hline S. Schwarzengrund & & $15^{1) 6)}$ & 4 & \\
\hline S. Senftenberg & $3^{5) 8)}$ & $41^{1)-3) 6)}$ & 16 & \\
\hline S. Singapore & & $1^{1)}$ & & \\
\hline S. Sinstorf & & 1) & & \\
\hline S. Subgenus & & & 1 & \\
\hline S. Subsp & $1^{13)}$ & $1^{1)}$ & 15 & \\
\hline S. Subsp I=0,7:- & & 14) & & \\
\hline S. Subsp I=03,10,15:eh:+:- & $1^{3)}$ & & & \\
\hline S. Subsp I=03,19:-:- & & & 1 & \\
\hline S. Subsp $I=04: 1, z 28:-$ & $2^{1)}$ & & & \\
\hline S. Subsp I=04,5:r:- & & $4^{1) 3)}$ & & \\
\hline S. Subsp $I=019$ & & & 1 & \\
\hline S. Subsp $I=6,7$ & & $3^{3) 4)}$ & & \\
\hline S. Subsp 6,7,2,0 & & & 1 & \\
\hline S. Tennessee & $1^{5)}$ & $12^{1)-3)}$ & 3 & \\
\hline S. Thomasville & & 191)2) & 4 & \\
\hline S. Tillburg & & $22^{1)}$ & & \\
\hline S. Typhi murium & $1^{5)}$ & $8^{1) 3) 10)}$ & 8 & \\
\hline S. Typhi murium, & & & & \\
\hline phage type 1 & & $1^{2)}$ & & \\
\hline S. Typhi murium NST & & $1^{10)}$ & 1 & \\
\hline S. Typhi murium 04 & & & 1 & \\
\hline S. Typhi murium O4, & & & & \\
\hline phage type 1 & & $1^{2)}$ & & \\
\hline
\end{tabular}


Table 12 (continued)

\begin{tabular}{|c|c|c|c|c|}
\hline \multirow{2}{*}{$\begin{array}{l}\text { Salmonella } \\
\text { serotypes }\end{array}$} & \multicolumn{2}{|c|}{ Raw materials } & \multirow{2}{*}{$\begin{array}{c}\text { Dust and } \\
\text { scrapings } \\
\text { from feed mills }\end{array}$} & \multirow[b]{2}{*}{ Compound feeds } \\
\hline & $\begin{array}{l}\text { Vegetable } \\
\text { feeds }\end{array}$ & $\begin{array}{c}\text { Feeds of } \\
\text { animal origin }\end{array}$ & & \\
\hline S. Typhi murium O4, NT & $1^{9)}$ & & & \\
\hline S. Typhi murium $O-4,5$, & & & & \\
\hline phage type 1 & & & 1 & \\
\hline S. Typhi murium $0-4,5$, & & & & \\
\hline phage type 8 & & & 1 & \\
\hline S. Typhi murium $0-4,5$, & & & & \\
\hline phage type 9 & & & 2 & \\
\hline S. Typhi murium $0-4,5$, & & & & \\
\hline phage type 15 & & & 1 & \\
\hline S. Urbana & & $6^{1) 10)}$ & & \\
\hline S. Weltswreden & & & 2 & \\
\hline S. Westhampton & & $3^{1) 10)}$ & & \\
\hline S. Wil & & & 3 & \\
\hline S. Worthington & & $1^{3)}$ & 4 & \\
\hline S.6,8:eh- & & 1) & & \\
\hline Total & 47 & 436 & 282 & 15 \\
\hline
\end{tabular}

* Codes for feeds of animal origin.

1) meat meal, 2) meat and bone meal, 3) feather meal, 4) greaves meal, 5) soya bean meal, 6) fish meal, 7) rape seed meal, 8) coconut, 9) maize meal, 10) blood meal, 11) flavor addetive for petfood, 12) wheat flakes, 13) defatted rape meal (Expro).

ous period. Twelve serotypes were isolated in 32 different samples.

The trend for a reduced number of meat-meal processing plants in Sweden, that could already be registered in the early 1980 s, has continued. The prohibition in 1987 to use meat from animals that have died of natural causes has profoundly changed the conditions for domestic production of meat-meal. Today, the production is mainly concentrated to 1 plant (Stidsvig).

Salmonella isolated from feed mills and feedstuffs. Isolations of Salmonella from feed mills and feed stuffs in Sweden during 1988-1992 are presented in Table 12. Salmonella was confirmed in 766 samples of raw material of vegetable or animal origin, and dust and scrape samples obtained from feed mills. In the preceding period (1983-1987), a total of 236 incidences of Salmonella were registered, which indicates a considerable increase during the last period (below).

A voluntary program for bacteriological control of feed has been in effect since 1960. In this program, the hygienic conditions of the feed were monitored by assaying 1 sample for each 100 tons of mash produced. The mash gave an indication of Salmonella in the raw materials, which were similar to those used for pelleted broiler feed.

Since 1960, several positive samples of Salmonella in Swedish feed mills have been observed. Particularly the pellet coolers have been found to be contaminated with Salmonella of different serotypes.

In 1991 end-point testing was replaced by a Hazard Analysis Critical Control Point ap- 
proach (HACCP)(Simonsen et al. 1987). The reason for this approach was because it aims at identifying the primary causes of contamination, e.g. raw materials, and production, storage and transportation procedures. The HACCP system consists of an analysis of hazards and assessments of their severity as well as identification of so-called Critical Points (CCP) (Simonsen et al. 1987).

Five samples for bacteriological control are collected each week from feed mills in which poultry feed is manufactured. Feed mills only producing cattle or swine feed collect 2 weekly samples. Since 1990, all samples are taken from fixed positions in the production chain, where the chances of finding Salmonella bacteria are the greatest. For feed mills manufacturing poultry feed, 2 of the samples are from the section of raw materials and 3 samples are collected after pelleting. If positive samples are detected the mill is notified immediately and further sampling and sanitation is initiated.

A significantly higher number of Salmonellapositive samples was found by using this technique rather than the previous analysis of ready-mixed feed.

Most of the positive samples were detected in the unloading areas and the intake elevator of the feed mills. Several positive samples were also detected in the aspiration system from the raw materials section as well as the premises around the pellet cooler. Very few positive samples were isolated from the inside of the pellet cooler or the top of the bins for ready-mixed feed.

\section{Conclusion}

The present compilation on the isolations of Salmonella in animals in Sweden during 19881992, shows a conspicuous decrease in the number of Salmonella outbreaks compared to previous reports. The large increase of positive samples in the feed manufacturing is mainly due to a new sampling method which facilitates the detection of Salmonella present in raw materials.

The presented data indicate that the officially adopted program of prophylactic measures against Salmonella has been successful.

\section{References}

Anonymous: Salmonella, 1992, Institut Pasteur, Paris.

Eld K, Gunnarsson A, Holmberg T, Hurvell B, Wierup M: Salmonella Isolated from Animals and Feedstuffs in Sweden during 1983-1987. Acta vet. scand. 1991, 32, 261-277.

Gunnarsson A, Hurvell B, Nordblom B, Rutqvist B, Thal E: Salmonella isolated from Animals and Feedstuffs in Sweden over the Period 1968-1972. Nord. Vet.-Med. 1974, 26, 499-517.

Hurvell B, Lagerquist $U$, Rutqvist $L$, Thal E: Salmonella Isolated from Animals and Feedstuffs in Sweden during 1963-1967. Nord. Vet.-Med 1969, 21, 289-305.

Karlsson K-A, Rutqvist L, Thal E: Salmonella isolated from Animals and Animal Feeds in Sweden during 1958-1962. Nord. Vet.-Med. 1963, 15, 833-850.

Kauffman F: Serological diagnosis of Salmonella species. Kauffman-White-Schema. Munksgaard, Copenhagen, Danmark 1972.

Lilleengen $K$ : Typing of Salmonella typhi-murium by means of bacteriophage. Acta path. microbiol. Scand. suppl. 77, 1948.

Mårtenson L, Holmberg T, Hurvell B, Rutqvist L, Sandstedt $K$, Wierup M: Salmonella Isolated from Animals and Feed Stuffs in Sweden during 1978-1982. Nord. Vet.-Med. 1984, 36, 371-393.

Popoff, M, Le Minor L: Antigenic Formulas of the Salmonella serovars. WHO Collaborating Centre for Reference and Research on Salmonella. Institut Pasteur, Paris, France. 1992.

Rutqvist $L$, Thal E: Salmonella isolated from Animals and Animal Products in Sweden during 1956-1957. Nord. Vet.-Med. 1958, 10, 234-244.

Sandstedt K, Gunnarsson A, Hurvell B, Nordblom B, Rutqvist L, Söderlind $O$ : Salmonella Isolated from Animals and Feed Stuffs in Sweden during 1973-1977. Nord. Vet.-Med. 1980, 32, 57-74. 
Simonsen B, Bryan FL, Christian JHB, Roberts TA, Tompkin RB, Silliker JH: Prevention and Control of Foodborne Salmonellosis through Application of Hazard Analysis Critical Control Point (HACCP). Int. J. Food Microbiol. 1987, 4, 227 247.

Thal E, Rutqvist L, Holmquist H: Salmonella isolated from Animals in Sweden during the Years 1949 to 1956. Nord. Vet.-Med.1957, 9, 822-830.

\section{Sammanfattning}

Salmonella isolerad från djur och fodermedel i Sverige 1988-1992.

En sammanställning har giorts beträffande antalet rapporterade salmonellaisolat från djur och fodermedel under perioden 1988-1992 i Sverige. Det är den åttonde 5 års rapporten i en serie som publicerats från Statens Veterinärmedicinska Anstalt (SVA) sedan 1949. Under den aktuella perioden rapporterades 602 utbrott av Salmonella hos djur, både husdjur och vilda djur. Jämfört med föregående 5 års period, när 760 utbott registrerades innebär det en reduktion om cirka $20 \%$.

Femtiosex olika serotyper identifierades, av vilka 19 tidigare inte isolerats hos djur i Sverige. År 1991, efter en utökad provtagning hos äggläggande höns noterades en tillfällig ökning av antalet utbrott hos fjäderfä. En anmärkningsvärt hög frekvens $(38 \%)$ av Salmonella observerades hos vilda ormar.

Före 1990 var salmonellakontrollen av industriellt tillverkat djurfoder huvudsakligen inriktad på den färdiga produkten. Den förändring som infördes 1990 innebar att provtagningen istället koncentrerades till fasta s.k. "kritiska punkter" i processlinjen d.v.s. avsnitt i processen, där risken för kontamination och tillväxt av Salmonella bedöms som stor (enligt HACCP-principen = Hazard Analysis Critical Control Point). Ett signifikant högre antal positiva prover av Salmonella hittades efter införandet av denna nya teknik för provtagning.

Slutligen konstateras att gällande bekämpningsprogram mot Salmonella bidragit till ett reducerat antal salmonellautbrott.

(Received June 6, 1994; accepted October 14, 1994).

Reprints may be requested from: M. Malmqvist, National Veterinary Institute, Laboratory of Bacteriology, P.O. Box 7073, S-750 07 Uppsala, Sweden. 
